\title{
IMPLEMENTATION OF LAW NUMBER 6 OF 2014 ON VILLAGES RELATED TO THE POLITICAL PARTICIPATION OF WOMEN IN VILLAGE REGULATION IN INDONESIA
}

\author{
Ani Purwanti'; Fajar Ahmad Setiawan ${ }^{2}$ \\ ${ }^{1}$ Faculty of Law, Universitas Diponegoro \\ ${ }^{2}$ Institute of Human Rights and Peace Studies, Mahidol University \\ Email: ani_purwanti81@yahoo.com
}

\begin{tabular}{l}
\hline Article Information \\
\hline Submitted: November 19, 2019 \\
Accepted: May 02, 2020 \\
Keywords: \\
affirmative action; substantive \\
representation; political \\
participation
\end{tabular}

\begin{abstract}
This article explores the affirmative action related to women's political participation in the village's decision-making process that results in village regulations. This article uses a law-based approach, it will also demonstrate the contrasting implications between affirmative action on the village legislative system and the regional parliamentary system (city, province, and state). The decision-making process in the village differs from the conventional Parliament, where the implications of the affirmative action of village law differ from the parliamentary system. This is due to the existence of the village deliberation where a group of women is mandated to be directly involved in direct deliberation. This feature facilitates bottom-up politics for gender equality and advocacy of women's rights in decision-making where female and group representatives can work shoulder-to-shoulder and safeguard one another on the agenda of Women's empowerment and gender equality. This is a unique advantage that does not exist in parliamentary politics because the quota system does not guarantee the representation of women ideologically in line with the interests of women they represent.
\end{abstract}

\section{Introduction}

The democratization of the Indonesian state gradually progressed. Such advances are characterized by the political transition of the former governmental system that was once authoritarian to a more democratic government. One of the early steps of democratization is to ratify the international human rights conventions. Some of these conventions are the basis for the development of women's rights such as the Convention on the Elimination of All Forms of Discrimination against Women (CEDAW) in 1980 and the International Convention on Civil and Political Rights (ICCPR), and the International Convention on Economic, social, and Cultural Rights in the year 2006. Besides, the Indonesian Government has also signed a commitment note for the Millennium Development Goals (MDGs) in 2000 which was followed by the Sustainable Development Goals (SDGs) in 2016.

Gender equality is a condition in which women and men are equally treated to legally recognized rights or the opportunity to pursue livelihood improvements. Gender 
equality is a critical issue at present due to increased awareness of women's discrimination that emerged by the culture and patriarchy system. Governments must respect, fulfill, and protect human rights, including women's rights, through the following laws and implementations. Understanding gender equality is essentially an overall human right because human beings are born with equal dignity. Therefore, through the framework of gender equality, the State must ensure the same treatment between the rights of women and men in politics, economics, society, and culture. There are three principles in gender equality i.e. 1) substantive equality, 2) non-discrimination, and 3) State obligations to respect, fulfill, and protect (Krook, 2008).

This act is a response from the Indonesian Government to the global movement to democratization. Therefore, there is a tendency that arises about the assurance of political representatives for the groups that are in the suburbs. One notable issue was the lack of representation of women in politics. To promote gender equality and the proliferation of female representatives in politics, the Indonesian Government is implementing affirmative action, a special action that supports the advancement of the underrepresented groups.

The most prominent of the affirmative acts of the female political representation is the legislative quotas where political parties are mandated to share $30 \%$ of their membership and voter nomination for women. The quota system is regarded as a breakthrough reform of the electoral system and Indonesian political representation that has implicated the proliferation of the number of female legislators in Indonesia. Regardless, the legislative quota system is widely welcomed as a first step towards the advancement of gender equality in Indonesia.

There is a good public acceptance, the implementation of affirmative action on women's political participation has expanded into a different political environment i.e. the village through the enforcement of Law Number 6 of 2014 on the village-known as the village ACT-and ministerial regulation. Internal affairs Number 110 of 2016 on the Village consultative Agency (People's consultative body). This law mentions the participation of women in article 58 paragraph (1) that, "the number of members of the village consultative Agency is stipulated by an odd number, at least 5 (five) people and at most 9 (nine) by taking into account the territory, women, residents, and the financial ability of the village". Also, the village law explained that the group of women is one element of the village society that can participate in the village deliberation, a consultative forum that is also followed by the Village consultative Agency and the village government to navigate the strategic things in the implementation of the village government. The village deliberation is a forum of decision-making that has been known for a long time and became part of the Indonesian national based on the fourth principle of Pancasila Led by Wisdom in the consultative/representative (Gumbira, S. W., Handayani, I. G. A. K. R., \& Tedjomurti, K. T. 2019: 199-218).

This article aims to analyze the consequences of implementing village law in the context of women's political participation in policy-making in village governance. The village law does not provide concrete rules and guidelines regarding how section 58 clause (1) of the village's Consultative board membership is interpreted as an affirmative action policy that can encourage the voice of women in the village policy-making process.

22 Yustisia Volume 9 Number 1 (January-April 2020)

Implementation of Law Number... 
Therefore, this article proposes one major problem that is investigated in the research below, namely; How can the village law promote women's political participation in the creation of village regulations?

\section{Research Methods}

This article is based on secondary data research i.e. data consisting of legal texts, literature, and pre-existing research documents (Soekanto \& Mamudji, 2003:1314). Besides, this article uses a legal approach in which legislation or regulations are interpreted under the context of purpose and legal norms (Barak, 2005; Ibrahim, 2005:61). Therefore, this approach suggests a conceptual investigation of the legislation from which the objective element (procedures) and subjective (legal intent) can be identified (Barak, 2005:88).

\section{Research Result and Discussion}

\section{A. Affirmative action, quota, and problem representation}

Affirmative actions are often defined as special actions that promote equality, affirmative backup access, and facilities that allow thriving to a position or resource that is appreciated for those who are discriminated (Dahlerup, 2008). Affirmative action is intended to promote the distribution of opportunities of progress and equal and equitable access to the work, education, management, and politics in which its chances of growing are impeded against groups that are experiencing discrimination - which cannot evolve - because of their identity - i.e. gender, sexuality, race, ethnicity, religion, and ideology. Affirmative action also demonstrates legal functions as a social engineering tool that intercepted unequal or discriminatory conditions through one of two measures; Limited imposition for the privileged followed by a reservation of access to the underprivileged and a substantial development measures against the underprivileged such as education and empowerment policies. Therefore, the outcome policy should be implemented in a manner that supports the advancement of groups that are discriminated by limiting either prominent majority domination or elevating minority positions and capabilities through empowerment policies. It demonstrates the double role of affirmative action as a constrictive regulation and social engineering tool. As a narrowing of law, affirmative action raises the group's privileges that are discriminated at the expense of the majority group already privileged. While the affirmative action as a social engineering tool, it acts as normative coercion with which norms, customs, and social institutions are established. Transformed into which social manipulation is intended for the advancement of social justice where all members of the community have the same fundamental rights, protections, opportunities, benefits, and obligations as the initial conditions of the implementation of Freedom (Gibelman, 2000; Barker, 1995:354; Figueira-McDonough, 1993).

One popular measure of affirmative action is the quota system in which the composition of actors in the decision making process is set according to the 
same identity representation (gender, race, ethnicity, religion) by percentage (Bjarnegard \& Zetterberg, 2014; Dahlerup, 2008; 2007; Krook, 2008; Young, 2000:150). Although the implementation of affirmative action is not necessarily associated with quotas, the quota system puts forward the importance of inclusivity in democracy as a basis to provide opportunities for discrimination groups (Young, 2000:144). In Indonesia, the quota system for the participation of women in legislative legislation was officially announced through Law Number 31 of 2002 on the political party-known as the Political Party act-and Law Number 12 of 2003 on parliamentary elections-known as the Electoral Act (Siregar, 2005). Both actions are then amended regularly in each election year. The quota system set the minimum limit for women's political participation to thirty percent. This quota system is a kind of "Legislative quota" where the specified threshold is set at the election nomination stage where the mandatory political party consists of $30 \%$ of women of the total membership and the voting candidate (Krook, 2008:350). Quotas are intended to intentionally modulate gender proportionality by involving actors in decision-making. This indicates that the quota system is more likely to be effective for increasing inclusiveness in the electoral system of representatives in which the constituent Division is reflected in the elected legislative body (Jones, 2009; Matland, 2006; Gray, 2003). Meanwhile, the quota system can also mean as a reservation of political space for the vulnerable groups and minorities at the expense of restrictions on more represented privileged groups (Dovi, 2009) Therefore, it is indicated that affirmative action on women's political participation is based on the concept of political representation.

Affirmative action-This quota system-is generally applied concerning political representatives to prioritize the interests of the people who are in the suburbs and minorities to progress decision making. Political representation is the act of creating a person's perspective and interest to present in the decision-making process through a political actor who speaks and acts on his behalf (Pitkin, 1967; Mansbridge, 2003:515-528). Given the assertive nature of affirmative action - as policy and regulation -, the results resemble two types of political representations which are descriptive. Descriptive representation implies that representatives of the elected representatives are legalized by similar resemblance - crazy if possible - with those represented, such as identity agreements (gender, gender, race, ethnicity, religion, etc. (Pitkin, 1967). These political forms of representation show the expansion of locus representation that is beyond territorial boundaries (Rehfeld, 2005; Masbridge 2003). Instead, they manifest the relationship of the principal-agent in which the legitimacy of representatives is based on the responsive and sound mobilization (principal) constituent by the representative (the agent) (Disch, 2015).

\section{B. The democratization of villages through village law}

In the context of Indonesia, the village has different characteristics of human settlements only a small group. In the year 2014, the Indonesian government 
declared the village law or Law Number 6 of 2014 on the village. According to the law, villages known differently as villages and indigenous villages are law-abiding communal entities that have territorial boundaries and sovereign authority to govern and manage government affairs and local Community initiatives, rights of origin and traditional rights that become the basis of the state's recognized and respected government system. The rights of origin and traditional rights are the original indigenous customs and traditions that make up the social, political, legal, economic, and cultural system of a village. Moreover, the village law regulates the principles of village governance, namely:

1) Recognition: State recognition of customary rights.

2) Subsidiarity: Local authority and decision-making body at the village level.

3) Diversity: Recognition and respect for the value system and norms that live in the village community without heed to the citizenship status and the rights and obligations that follow.

4) Collectivism: Active participation and cooperation and respect for each other between village institutions and community-related Village development groups.

5) Cooperation: The habits of life help each other unconditionally.

6) Collective : Cultural habits of village communities as one big family

7) Deliberative: The Decision-making process is based on the result of deliberation between parties representing the interests of the villagers.

8) Democracy: The Village governance system is based on public approval or popular vote.

9) Independence: Village governments must be independent and self-reliant in carrying out their duties and responsibilities to manage and build villages.

10) Participation: Village communities must be actively involved in the decisionmaking process in the governance of the village.

11) Empowerment: The programs, policies, and agendas undertaken by village and community governments must have an impact on improving the quality of life and welfare of the community.

12) Sustainable: Efforts made through the coordination, integration, and synchronization of all elements in the village government in the planning and implementation of Village development Program

The village law replaces government regulation on the village under the previous Regional Autonomy Act (Law Number 32 of 2004). The village law strengthens the village's legal status, enhances their authority and responsibilities, and recognizes indigenous, legal village life based on tradition and customs. The law also provides villages with all the complete governing system governance, organizing the villages into autonomous and democratic. The village governance system, as well as the upper-level governmental system (States, provinces, and cities), consists of executive and legislative institutions. The first is led by a village leader assisted by bureaucrat workers, while the 
latter is the village consultative Board. Both institutions work together as a form of governmental unity through which the village has the authority to announce their own policies and rules concerning the life of the villagers. The conception of village governance resembles democratization such as the decentralization of power from the state to the lowest or Upper-level government. This is due to the rise of concern for the backward villages and inequality that led to the high level of poverty in the rural areas due to lack of space and authority to develop independently which was the consequence of a centralized governance system during the New Order government. (Gibson 2017, Antlov 2003). However, given the typical and historical ontological origins of the village, the village law recognizes such authenticity by granting autonomy to the village government in consideration of indigenous and decentralized rights.

The village law also implements general democratic procedures for executive and village legislatures such as elections. Village leaders, or chief executive powers, and members of the village consultative Agency were elected democratically through one of two ways, the election or the collective deliberation process. The authority of the village government is as a local autonomous government whose authority is granted, secured, and respected by the upper government-especially the state-. However, such authority is still limited under the administrative hierarchy and thus, it is the rule of the village governance system. In contrast, the village consultative Agency was designed to be an extraordinary "parliamentary" village. According to the village law, the village consultative Agency consists of popularly selected members-or appointed-with the least number of members with five members and at least nine members. The role of the village consultative Agency is also an ordinary parliamentary institution such as; 1) propose, consider, and approve the draft law along with the village head, 2) accommodate and convey the aspirations and opinions of the villagers, and 3) supervise the village government and village head.

The conception of the village in the village law is unique in combining indigenous communities with modern democratic systems. This is to ensure that increased decentralization will lead to the proliferation of democratization and ultimately, the improvement of life in the village. One of the mechanisms is to provide a check-and-balance mechanism to keep the rulers and village legislators accountable to the people. The participation is also in the village law which provides the same consultation mechanism, namely the village deliberation (village deliberation). The village deliberation is a designated public space where the village government, the village consultative Agency, and the constituents can meet and negotiate on strategic and urgent matters in the context of village governance. The village deliberation is the only mechanism in which the accountability of rulers and legislators can be examined directly by the constituents in the public space. However, considering the intention of democratization and instituting villages into the Indonesian administrative system, the village deliberation is compatible with the socio-cultural background of Indonesian villages. 
The village democracy system enacted by the village law resembles a kind of democracy deliberative as the core of the village's decision-making system (Hamid, 2018). This is demonstrated in the parliamentary resemblance to the village consultative Agency in the process of making policies and deliberative in which the procedure is similar to the village deliberation. Further, the conception of the village government as set forth in the village law may show the formalization of the existing village culture. A culture that has been democratic as deliberate (Prasetyo, 2005). Such an action to democratize the village by foresting the deliberative democracy that already existed in the village culture into the government system demonstrates the village law's expectation that the village government should accommodate, convey, and manifest communitybased development (IDS, 2017; Antlov et al, 2016; Bebbington et al, 2006; 2004). As an effort to balance development inequality towards the Millennium Development Goals, village law is meant to synchronize development across Indonesia at every regional level as a whole. Therefore, the conception of village governance under the village law suggests the change in capacity, constraints, and opportunities to improve government responsiveness to the needs of the community. Besides, it is hoped that the village government's autonomy will empower the village community.

\section{Women's political participation in village law}

Considering the value of deliberative democracy in the village government, the village LAW also emphasized the importance of inclusion of groups and minorities in the decision-making process, resulting in affirmative action. Unlike the legislative quota which only mandates the participation of women in political parties, affirmative action on women's political participation in the village LAW regulates the representation of a clear woman in the formation of a village member agency Permusyawaratan. A member of the Village consultative Agency is considered a democratically elected village representative by its diversity constituency-based not only on territorial divisions. Article 58 paragraph (1) of the village law stipulates that the representation of women should be considered in connection with the membership in the Village consultative Agency. Women are a distinctive and definitive constituent along with the region, environment, and financial capabilities of the village for the election of the village's Consultative board. As an institution of political representatives, the village law mandated that there should be a presence of female representatives in the village consultative agency even though the law does not specify quotas.

Considering the number of small formations as members of the village consultative Agency, representatives ' considerations should not be taken quantitatively. It is confirmed by the Government Regulation Number 4 of 2014 and regulation of the Minister of Home Affairs Number 110 of 2014 where only one member of the Village Consultative Board can be selected under the constituent of women. However, this does not mean those female representatives 
are reduced to a maximum because prospective women can become members of the village consultative Agency through other electoral districts. This is due to the same representation of consideration of all the urgent things in the village and given the little amount of membership allowed. Therefore, there could be more than one female representative at the Village consultative Agency. The provisions of such affirmative action are merely legal obligations to ensure that the interests of women are represented and conveyed in the decision-making process.

The political participation of women in the village consultative Agency is not only regulated in terms of representation but also in terms of direct participation in the deliberate decision-making process. The village deliberation is the deliberation media as stipulated in the village law where the village government, members of the Village Consultative Board, and constituents can discuss village-related issues. The constituency consists of representations of various social elements as follows:

1) Indigenous people

2) Religious figures

3) Social figures

4) Education figures

5) Representation of farmers

6) Representation of fishermen

7) Representation of craftsmen

8) Representation of women

9) Representations of child protection advocates, and

10) Representation of the poor

This can be ensured that the concept of village decision making under the village law assimilated with modern democracy procedures with the customary system and traditions of Indonesian villages that already exist. It creates a sort of political representation in which the communication between representatives and the represented associated with the making of village policy is much more intense and frequent. The village consultative and village Deliberation agency is an important political medium for women to fight for their interest in the policy-making process in villages affecting their lives. The affirmative action set in the village LAW is far more assertive than the legislative quota because provisions for female representatives are mandated directly to the membership of the Village consultative Agency and the village deliberation.

\section{Challenges of Village Law Implementation to Promote The Political Participation of Village Women}

The political system of government policymaking and bureaucracy as stipulated in the village LAW demonstrates the characteristics that correspond to the customs and traditions of the village as a unified society. The deliberation 
process in policymaking is designed to be accommodating as possible, where the communication between representatives and constituents - the villagers and the interest groups - is responsive and sensitive to the needs of the villagers. Given the democratic purpose of the village law, the draft political system is intended not only for community-based development but also for the advancement of less fortunate and disadvantaged groups, such as women. However, given that the village governance system combines democratic procedures with the habit of village deliberation, it shows that the procedure of making an inclusive policy for the groups and minorities is due to two representations of the Village consultative Agency and the village deliberation. Therefore, it is the essence of community-based development in which communities (or in certain groups, of disinterested and minorities) are actors in proposing and championing their interests in the village decision-making process, regardless, the challenge persists with a twist as a burden to actualize the opportunity to thrive only placed on actors, hence village communities.

External factors such as globalization, trade, and economic policy impact the development policy of any type of political community. Therefore, the creation of a conducive environment for women's participation in politics and development can not be seen only within the boundaries of a country. It should be attributed to the global factor. Thus, the responsibility for creating an environment that supports gender equality and the advancement of women as a joint responsibility is in the hands of national and international societies. The mutually rooted layer of gender inequality is rooted in power structures at national and international levels. The policy of development and globalization has led to increased poverty, exclusion, and marginalization. Structural strength must be challenged and altered by relating it to people's rights. Without changing the structural barriers of socio-cultural, political, and economic at the national and international level, the goal of gender equality or equivalent participation of women in politics and development will remain impossible to achieve. Other important elements in the environment are possibly related to the nature of democracy and the level of democratization in society. A participatory and decentralized form of government creates a greater space for citizens to participate in governance processes and structures. It also creates space for greater interaction between countries and communities.

Human capacity depends on the availability of resources such as education, health, and work that builds ability and enlarges human choices. Access to education, health, and employment is directly related to the ability of women to create space for themselves in politics and development. The awareness of women about their political rights is another important element for individual and female collective agencies. Political awareness through building a transformative community is a sustainable way to change politics and development. The movement and civil society of strong women is another condition of the enabling environment that can influence the direction of politics and development that benefit women. The role of triple women in the field of 
productive, reproductive, and community management should inform the efforts to create a supportive environment for women's political participation. The provision of childcare work and maintenance is essential to allow women to participate in the development process.

\section{Case study: Semarang District}

In 2018, the Government and regional representatives of Semarang Regency imposed two laws; The regional law of Semarang District Number 4 of 2018, which regulates village governance and decree of the regent of Semarang Regency Number 21 of 2018, which regulates village electoral mechanisms. As for The village's consultative body (hereinafter referred to BPD) membership, these laws have set their membership formats such as a) The BPD consists of 5, 7, or 9 members depending on the population size, and; b) BPD membership must be selected based on the representation of women and territories through direct selection or community deliberation, with the warning that all BPD will have only one female member representing a female representative.

The above Format explains that there is a sort of chair designated for a particular purpose, which in this case there are two; Regions and women. As for the seat of female representatives, the selection mechanism is specific and targeted to the female population in the village, so that the entire election of female representatives is done by and only for women. Although the seat is only designated one for each $B P D$, women can still be members of the BPD but without prescribed procedures. This is shown in the following steps: 1) The candidacy for the designated female seat is only to be proposed through the agreement of deliberation from a representative of the local women group; 2) Female representative seat selection can use two methods; Direct selection by a legally available female elector or deliberation involving a female social figure approved by the village.

Based on the government regulation of the regent of Semarang Number 4 of 2018 and decree of Regent Number 21 of 2018, the selection of female representatives in the BPD includes only female villagers-who have the right to vote and be authorized through citizen recognition-to ensure that the representation of women not only in the physical sense but also in the alignment of interests between prospective representatives and constituents. The selection procedure begins with the selection of female candidates. Both regulations stipulate that, based on territorial consideration, there is only one female candidate to be delegated as the female candidate of the region's constituents. Delegates are determined by a consensus of the constituent deliberations of women of the Community and environmental groups.

This discussion Forum consists of two members of the family Welfare Program, one representing a community and the other representing a group of neighbors, and two female figures. Subsequently, candidates who were elected formally became candidates for female representatives from the electoral district. The next and final step is the village-level elections, where one female candidate is chosen as the female representative of the BPD. There are two selection mechanisms available, the Consensus forum and the live voting system. In one of these, the selection of female 
representatives will be conducted by a village-level female constituency, including one member of the branch family planning, a member of the community members branch of family planning, and two female group figures.

These two local regulations further broaden the role of women in village politics outside of electoral competitions. Policymaking in the village not only focuses on executive and legislative considerations but also engages the public in these meetings. The debate site is referred to as the village deliberation, which has the following functions; 1) Allow the Government to consult with the communitythrough constituent representation-regarding policies and regulations, and 2) allows the government to report actions and actions taken during the administrative period. Therefore, the village deliberation is a type of public meeting where the village government, $\mathrm{BPD}$, and constituent representatives of the public can meet and negotiate about the affairs of the village. The Forum also manifests the BPD's right to question the village government about government affairs. Regarding the participation of women, constituent women can also be involved in the forum, as mandated by the village LAW. Therefore, there are two ways for women to participate in village policy making, either internally as a BPD member or externally through a village deliberation. We analyze that this law (Government regulation of Semarang District Number 4 of 2018 and decree of Regent Number 21 of 2018) employs two people to empower women in politics; Self-participation and self-representation. Self-participation means that the village selection mechanism encourages the full involvement of the village woman in every step of the election. While selfrepresentation means that this designated mechanism is intended for designated seats also i.e. female representatives so that only women who are committed and supported by the female constituents can win the elections.

The idea of gender equality in Indonesian politics has surpassed the country's level to a much smaller level of administration along with a surge in the decentralized policy. Affirmative action for female representation has been adopted in regional politics as well, including the village. Aided by legal autonomy as part of decentralization, local governments can enforce their policies and regulations, which means that they can take that freedom to develop more effective methods to realize gender equality in politics and villages in the region. This is shown in our research held in Semarang Regency where the government has issued two regulations, the government regulation of Semarang District Number 4 of 2018 and decree of Regent Number 21 of 2018, on the selection of villages and mechanisms. As for affirmative action, this law mandated the designated Chair for the representation of women in every country consultative agency in Semarang district.

The mechanism of selection of BPD members in Semarang district has a great potential to increase the expansion capability of women agencies in village politics. It is demonstrated from the use of two values in the policy; Self-participation and selfrepresentation where women of the village are the center of all electoral mechanisms for the seat of designated female representatives, both as voters, candidates, political support, etc. This mechanism respects and adopts deliberative political living 
habits, mixed with modern democracy. The two regulations of Semarang Regency (Government regulation of Semarang District Number 4 of 2018 and decree of Regent Number 21 of 2018) can help empower village women in Semarang District.

Gender quotas emerged as a global tractate strategy to correct women's historical exceptions from the formal political arena. During the latter half of the 20th century, many countries have institutionalized gender quota either voluntarily or by law. The gender quota is colored with the discursive controversy. Without arguing over two different views, this section summarizes some of the issues highlighted in gender quota comparison studies. There is a clear consensus in the literature that gender quotas are an effective tool in addressing women's exclusion and ensuring their presence in formal political structures. However, controversy began surrounding vital questions to the extent that women's presence in political structures has led to the mainstreaming of effective gender issues in politics. This has raised the problem of the nature and modalities of gender and its limits to empower women in politics.

The gender quota is instituted in the context of the gender gap, which is structural and systemic. Without addressing the structural constraints on women's political exclusions, the inclusion of them through gender quotas cannot produce effective representation. (Rai, 2000) has emphasized the same points as arguing that "although the quota is important in overcoming the exclusion of women from public politics, they can only form a part of a multi-faceted strategy for the empowerment of women, which should be along with increased political participation also involves the ion redistribution of socio-economic resources in society." Women who do not have civil and economic rights cannot exercise their political rights entirely. Gender quotas, therefore, need to be attributed to social and economic redistributive justice in the community. The gender quota is also full of female essentialist assumptions as a different group with different perspectives and universalization of women as a category. Women are not homogeneous groups. They are divided along class lines, ethnicity, religion, and the village/city background. Elite women's dominance in the political structure because state quotas call for the placement of gender quotas in a framework of diversity and distinction to ensure women's political empowerment. The gender gap in politics cannot be overcome by simply bringing more women into the system. This is also a policy issue and the results cannot be resolved unless there are mechanisms that support and provide an environment that enables it to work effectively. This makes the properties and processes of the quota system become the center of affirmative action actions. Experience shows that quota modalities must be direct, empowering, and enabling women to develop their constituency. Lastly, broader political and democratic contexts are equally important for determining the success of gender quotas. The quota debate lies globally within the framework of liberal democracy and citizenship. The expansion of citizenship for everyone, regardless of their color, beliefs, and gender, has become the basis of modern liberal Democracy (ANN, 1998).

In the form of representative democracy that is practiced in many countries, voters are not free to use their right to vote. The behavior of selecting most voters 
continues to be determined by the primordial loyalty and patriarchy relationship. In this political context when the gender quota is instituted, the quota does not necessarily bring gender equality because this is the way some of these countries negotiate with modernity and pluralism by bringing the one that is crossed to the mainstream on the condition of the elite patriarchy of men. When women enter into political quota with these provisions, they cannot exceed public-private gaps and are forced to conduct politics only in the public arena. Women in politics have failed to make the family part of the pubic arena, although in reality when they enter political public spaces they do not cease to be private individuals. My argument is that in the context of modern patriarchic democracy when women enter politics through gender quotas, they cannot change sexual politics in State institutions. Instead, they were forced to play with the male requirements. Therefore, it was concluded that without broader political transformation, gender quota could not lead to women's political empowerment.

\section{Conclusion}

The idea of gender equality in Indonesian politics has surpassed the country's level to a much smaller level of administration along with a surge in the decentralized policy. Affirmative action for female representation has been adopted in regional politics as well, including the village. The village law has implemented a complete system of government that is unique and accommodating to the background of the village of Indonesia where executives (village government) and legislative bodies (the Village consultative Agency) can be secured by the constituent directly through the discussion forum that is the village deliberation. This suggests that the type of democracy deliberative assimilated into a village culture that manifests communitybased development as the spirit of collectivism and cooperation is the main habit of Indonesian villages. As a progressive step towards democratization, decentralization, self-empowerment, and indigenous rights, the village law has also set an affirmative action for women's political participation. Unlike the legislative quotas of parliamentary systems that tend to be reductive to mainstream gender, the affirmative action in the village law establishes women's political participation in two ways; Representatives at the Village consultative Agency, and the participation of female interest groups in the village deliberation. This inclusive double way of deliberation has consequences that, good or bad, can determine the increase in gender equality and the quality of life of women in the village. Such consequences are the opportunities and responsibilities given solely to the village community as self-governing communities to actualize the interests of the people. Therefore, the responsibility to struggle politically in representative politics lies entirely with women, and the female interest groups, in negotiating, haggling, proposing, influencing, and actualizing the village policy of gender mainstreaming or gender equality.

The autonomy of legislation as part of decentralization, local governments can enforce their policies and regulations, which means that they can take the freedom to 
develop more effective methods to realize gender equality in politics and villages in the region. This is shown in our research held in Semarang Regency where the government has issued two regulations, the government regulation of Semarang District Number 4 of 2018 and decree of Regent Number 21 of 2018, on the selection of villages and mechanisms. As for affirmative action, this legislation mandated the designated Chair for the representation of women in each village Representative Council in Semarang district. A seemingly complete selection mechanism also uses two values; Self-participation and self-representation where women of the village are the center of all electoral mechanisms for the seat of designated female representatives, both as voters, candidates, political support, etc. This mechanism respects and adopts deliberative political living habits, mixed with modern democracy. Therefore, this law indicates well-being is not only a democratic system of government but also a progressive political and social culture that is inclusive of women's problems and as an important part of gender mainstreaming in village life.

\section{BIBLIOGRAPHY:}

Books:

Ann, P. (1998), Feminisms and Politics, Oxford University Press

Barker, R. L. (1995). Social Work Dictionary, $3^{\text {rd }}$ ed. Washington, District of Columbia: NASW Press

Fishkin, J. S. (2011). When the People Speak: Deliberative Democracy and Public Consultation. Oxford: Oxford University Press

Ibrahim, J. (2006). Teori dan Metodologi Penelitian Hukum Normatif. Malang: Bayumedia Publishing

Pitkin, H. (1967). The Concept of Representation. Los Angeles: UCLA Press

Salim, A., et al. (2017). Indonesia's Village Law: Enabler or Constraint for more Accountable Governance? Making All Voices Count Research Report. Brighton: IDS

Fishkin, J. S. (2011). When the People Speak: Deliberative Democracy and Public Consultation. Oxford: Oxford University Press

Rai, M. S. (2000) International Perspective on Gender and Governance, Macmillan Press: Great Britain.

Soekanto, S. \& Mamudji S. (2003). Penelitian Hukum Normatif. Jakarta: Raja Grafindo Persada

Young, I. M. (1999). Justice, Inclusion and Deliberative Democracy. In Deliberative Politics, Stephen M. (ed.), Oxford: Oxford University Press

\section{Journals:}

Antlov, H. (2003). Village Government and Rural Development in Indonesia: the New Democratic Framework. Bulletin of Indonesian Economic Studies, 39(2), 193-214 
Antlov, H., Wetterberg A. \&Dharmawan L. (2016). Village Governance, Community Life, and the 2014 Village Law in Indonesia. Bulletin of Indonesian Economic Studies, DOI: 10.1080/00074918.2015.1129047

Baldez, L. (2004). Elected Bodies: The Gender Quota Law for Legislative Candidates in Mexico. Legislative Studies Quarterly. 29(2). 231-258

Balington, J. \&Karam A (eds.). (2005). Women in Parliament: Beyond Numbers.Stockholm: International Institute for Democracy and Electoral Assistance

Barak, A. (2005). Purposive Interpretation in Law. New Jersey: Princeton University Press

Bebbington, A., Dharmawan L., Fahmi E. \& GuggenheimS. (2006). Local Capacity, Village Governance, and the Political Economy of Rural Development in Indonesia. World Development, 34(11). 1858-1976

(2004). Village Politics, Culture and Community-Driven Development: Insights from Indonesia. Progress in Development Studies. 4(3). 187-205

Bjarnegard, E. \& Zetterberg P. (2014) Why are Representational Guarantees Adopted for Women and Minorities? Comparing Constituency Formation and Electoral Quota Design within Countries. Representation. 50(3). 307-320

Celis, K., Childs S., Kantola J., Krook M. L. (2008). Rethinking Women's Substantive Representation. Representation. 44(2), 99-110

Clayton, A. (2015). Female Leadership, Electoral Gender Quotas and Women's Political Engagement: Evidence from A Randomized Policy Experiment. Comparative Political Studies. 48(3). 333-369

Dahlerup, D. (2008). Gender Quotas - Controversial But Trendy. International Feminist Journal of Politics. 10(3). 322-328

(2007). Electoral Gender Quotas: Between Equality of Opportunity and Equality of Result. Representation. 43(2). 73-92

Disch, L. (2011). Toward a Mobilization Conception of Democratic Representation. American Political Science Review. 105(1). 100-114

(2012). Democratic Representation and the Constituency Paradox. Perspectives on Politics. 10(3). 599-616

Dovi, S. (2009). Hanna Pitkin, the Concept of Representation. The Oxford Handbook of Classics in Contemporary Political Theory, Jacob L. (ed.), Oxford: Oxford University Press

Figueira-McDonough, J. (1993). Policy Practice: The Neglected Side of Social Work Intervention. Social Work. 38(2), 179-188

Gibelman, M. (2000). Affirmative Action at the Crossroads: A Social Justice Perspectives. The Journal of Sociology \& Social Welfare. 27(1), Available at https://scholarworks. wmich.edu/jssw/vol27/iss1/9

Gray, T. (2003). Electoral Gender Quotas: Lessons from Argentina and Chile. Bulletin of Lain American Research. 22(1). 52-78 
Gumbira, S. W., Handayani, I. G. A. K. R., \& Tedjomurti, K. T. (2019). The Urgency of Presidential Policy to Revitalize and Maintain the Existence of Cooperatives Based on Pancasila. Sriwijaya Law Review, 3(2), 199-224

Habermas. J., Lennox S \& Lennox F. (1974). The Public Sphere: An Encyclopedia Article, New German Critique. 3. 49-55

Krook, M. L. (2008) Quota Laws for Women in Politics: Implications for Feminist Practice. Social Politics. 15(3). 345-368

Matland, R. E. (2006). Electoral Quotas: Frequency and Effectiveness, in Women, Quotas, and Politics, ed. Dahlerup D. New York: Routledge

Prasetyo, P. S. (2005). Democracy in the Indonesian Village Society: the Impact of Local Autonomy Policy and the Role toward Democratization in Village Society. Berlin \& London: LIT Verlag

Purwanti, A. (2015, April). Quota Laws for Women in Politics: Implementation in Indonesia. Conference Proceedings, Kuala Lumpur International Business, Economics and Law Conference. 6(4). 18-19

Rehfeld, A. (2006). Towards a General Theory of Political Representation. The Journal of Politics. 68(1). 1-21

Rhoads, E. (2012). Women's Political Participation in Indonesia: Decentralisation, Money Politics, and Collective Memory in Bali. Journal of Current Southeast Asian Affairs, 31 (2), 35-36

Schwindt-Bayer, L. A. (2009). Making Quotas Work: the Effect of Gender Quota Laws on the Election of Women. Legislative Studies Quarterly. 34(1). 5-28

Siregar, W. Z. B. (2005). Parliamentary Representation of Women in Indonesia: The Struggle for a Quota. Asian Journal of Women's Studies, 11(3). 36-72

$36 \quad$ Yustisia Volume 9 Number 1 (January-April 2020)

Implementation of Law Number... 